\title{
Productive and qualitative characteristics of strawberry genotypes in the Plateau of the State of Santa Catarina, Brazil
}

\author{
Características produtivas e qualitativas de genótipos de morangueiro no Planalto Catarinense
}

\author{
Daniel Suek Zanin ${ }^{1 *}$, Juliana Martins de Lima ${ }^{2}$, Marllon Fernando Soares dos Santos ${ }^{2}$, Katiana \\ Vanusa Tillwitz ${ }^{2}$, Antonio Felippe Fagherazzi ${ }^{2}$, Adrik Francis Richter ${ }^{2}$, Aike Anneliese Kretzschmar ${ }^{2}$, \\ Leo Rufato ${ }^{2}$
}

${ }^{1}$ Universidade Estadual de Londrina, Londrina, PR, Brasil. *Author for correspondence: dsuekzanin@gmail.com

${ }^{2}$ Universidade do Estado de Santa Catarina, Lages, SC, Brasil.

Submission: 08/08/2019 / Acceptance: 06/03/2020

\begin{abstract}
To produce strawberries on a commercial scale, it is necessary to choose the cultivars best adapted to the growing site. This work aimed to compare strawberry genotypes regarding production and fruit quality, in the municipality of Lages, State of Santa Catarina, Brazil, during the 2017/2018 harvest season. In this work, 15 genotypes were evaluated, five commercial cultivars and ten advanced selections. The experimental design was in randomized blocks, with four replicates and plots of 11 plants. The cultivation system used was in the soil of an open field, in beds of approximately 90 centimeters, with three rows per bed. Planting distance was of 30 centimeters between rows and plants. The Sabrina cultivar showed the highest production $\left(1,231.77 \mathrm{~g} \mathrm{plant}^{-1}\right)$ and number of fruits $\left(78.48\right.$ fruits plant $\left.{ }^{-1}\right)$. The highest quality fruits were obtained from the selections FRF PIR 256.4, FRF 104.1, FRF 57.6, FRF LAM 119.1 and cultivar Pircinque, characterized by soluble solids/titratable acidity ratios above 15 . In the productive cycle in question, cultivar Sabrina presented the best performance, demonstrating the potential for recommendation to the producers of the South Plateau of State of Santa Catarina.
\end{abstract}

KEYWORDS: Fragaria $x$ ananassa Duch, adaptation, advanced genotypes, soil cultivation.

\begin{abstract}
RESUMO
Para produzir morangos em escala comercial, é necessário escolher as cultivares melhor adaptadas ao local de cultivo. Objetivou-se com este trabalho confrontar genótipos de morangueiro quanto a aspectos de produção e qualidade de frutos, no município de Lages, em Santa Catarina, no ciclo agrícola 2017/2018. Foram avaliados 15 genótipos, sendo cinco cultivares comerciais e dez seleções avançadas. O delineamento experimental utilizado foi em blocos casualizados, com quatro repetições, e parcelas constituídas por 11 plantas. O sistema de cultivo utilizado foi no solo, em campo aberto, em canteiros com aproximadamente 90 centímetros de largura, com três linhas de plantio por canteiro. A distância de plantio foi de 30 centímetros, entre fileiras e plantas. A cultivar Sabrina obteve a maior produção $(1.231,77 \mathrm{~g}$ planta $\left.^{-1}\right)$ e número de frutos $\left(78,48\right.$ frutos planta $\left.{ }^{-1}\right)$. Com as seleções FRF PIR 256.4, FRF 104.1, FRF 57.6, FRF LAM 119.1 e a cultivar Pircinque se obtiveram os frutos de qualidade superior, caracterizados por médias acima de 15 para a relação sólidos solúveis / acidez titulável. No ciclo produtivo em questão, a cultivar Sabrina apresentou o melhor desempenho, demonstrando potencial para ser recomendada aos produtores da região do Planalto Sul Catarinense.
\end{abstract}

PALAVRAS-CHAVE: Fragaria $x$ ananassa Duch, adaptação, genótipos avançados, cultivo no solo.

\section{INTRODUCTION}

Strawberry (Fragaria $x$ ananassa Duch) is the most important socioeconomic species within the berries group at a global level, with 395,844 hectars harvested in 2017 , followed by raspberries $(118,219$ ha) and blueberries (109,541 ha) (FAO 2019). According to the Food and Agriculture Organization, in 2017, the major strawberry-producing countries were China $(3,717,283 \mathrm{t})$; the Unites States of America $(1,449,280 \mathrm{t})$; Mexico (658,436 t); Egypt (407,240 t), and Turkey (400,167 t).

In the 2015/2016 harvest season, Brazil produced 155,440 t of strawberries in approximately 4,300 ha, resulting in a yield of $36.15 \mathrm{t} \mathrm{ha}^{-1}$ distributed between the states of Minas Gerais $(74,000 \mathrm{t})$, Paraná $(21,450$ 
t), Rio Grande do Sul (20,350 t), São Paulo (9,900 t), and Santa Catarina (9,900 t) (FAGHERAZZI et al. 2017a). This culture demands intensive management and high investment in inputs and infrastructure. Although it allows a good financial return, strawberry cultivation can be a risky activity, especially when carried out in areas inferior to one hectare (RONQUE et al. 2013).

One of the determinants of success in strawberry production is the choice of correct cultivar, considering that interactions between genotypes and environments may occur (COSTA et al. 2016). The adaptability of a strawberry cultivar is defined mainly by the following factors: temperature, photoperiod, and the interaction between them. These factors control the beginning and end of the productive phase since flowering and fruiting only occur under certain temperature and photoperiod ranges, which vary for each cultivar (HONJO et al. 2016). Cultivar selection also interferes in all aspects of the productive chain, such as planting season, use of correctives and fertilizers, spacing adequacy, harvesting point, and shelf life (FAGHERAZZI 2017).

The strawberry cultivars used in Brazil originate mostly from the United States, especially from breeding programs developed in the universities of California and Florida. To a lesser extent, there are also cultivars originated of Spanish breeding programs. Import is done by companies that buy seedlings from Chilean and Argentine nurseries (ANTUNES \& PERES 2013). Under Brazilian conditions, these cultivars do not always express their maximum yield potential and fruit quality and are often very susceptible to phytosanitary issues (OLIVEIRA \& BONOW 2012).

Furthermore, some cultivars are introduced in Brazilian territory without previous studies on their adaptability, which may result in losses to farmers (PÁDUA et al. 2015). This happens because, the strawberry culture is affected by the natural conditions of the production site, and the cultivars tend to present the maximum productive performance only in conditions similar to where they were developed (HANCOCK et al. 2008). Thus, germplasm is a tool used to increase the number of cultivars available to producers, improving the chances of obtaining genotypes adapted to the different producing regions (FAGHERAZZI et al. 2017b).

In this sense, in 2012, the Universidade do Estado de Santa Catarina (UDESC) has established a cooperation agreement with the institution 'Consiglio per la Ricerca in Agricoltura e L'Analisi Dell'Economia Agraria - Centro di Ricerca Olivicoltura, Frutticoltura e Agrumicoltura' (CREA-OFA-FRF) from Italy, to perform adaptability studies with Italian genotypes under Brazilian conditions (FAGHERAZZI 2013). These genotypes are evaluated by several productive cycles at different locations to confirm or discard their potential for commercial use. Through this project, in 2016, two strawberry cultivars were made available for use in Brazil, Pircinque and Jonica, both developed in Italy and successfully tested in Brazil (FAGHERAZZI 2017).

This work aimed to evaluate strawberry genotypes, from Italian, North American, and Spanish origin, in the South Plateau of the state of Santa Catarina, Brazil, regarding production characteristics and physicalchemical quality of fruits.

\section{MATERIAL AND METHODS}

The experiment was carried out at the Center of Agroveterinary Sciences of the Universidade do Estado de Santa Catarina (CAV/UDESC), in the municipality of Lages, SC, Brazil, during the 2017/2018 harvest season. The area is at the coordinates $27^{\circ} 47^{\prime} 05^{\prime \prime}$ South, $50^{\circ} 18^{\prime} 08^{\prime \prime}$ West, at an altitude of 906 meters above the sea level. The average maximum and minimum temperatures, as well as the monthly rainfall during the period in which the experiment was conducted are described in Table 1.

The experiment consisted of 15 genotypes, of which five were commercial cultivars, namely Albion (North American); Sabrina (Spanish); Irma, Jonica, and Pircinque (Italian). The remaining ten genotypes were advanced selections from CREA-OFA-FRF (Italy), namely FRF 57.6, FRF 104.1, FRF 191.2, FRF LAM 263.1, FRF LAM 269.18, FRF LAM 119.1, FRF PA 109.2, FRF PIR 256.4, FRF PIR 79.6, and FRF PIR 75.8. These genotypes are hybrids produced by averages of biparental crosses.

Regarding the photoperiod response, these genotypes are classified as follows: A) short-day genotypes - Jonica, Pircinque, Sabrina, FRF LAM 119.1, FRF LAM 263.1, FRF LAM 269.18, FRF PA 109.2, FRF PIR 75.8, FRF PIR 79.6, and FRF PIR 256.4; B) day-neutral genotypes - Albion, Irma, FRF 57.6, FRF 104.1, and FRF 191.2. 
Table 1. Average minimum and maximum monthly temperatures $\left({ }^{\circ} \mathrm{C}\right)$ and monthly precipitation $(\mathrm{mm})$ during the period in which the experiment was conducted, in the municipality of Lages,SC, Brazil.

\begin{tabular}{llllll}
\hline & May/17 & Jun/17 & Jul/17 & Aug/17 & Sep/17 \\
\hline Mean maximum temperature $\left({ }^{\circ} \mathrm{C}\right)$ & 17.9 & 16.2 & 17.9 & 17.4 & 22.0 \\
Mean minimum temperature $\left({ }^{\circ} \mathrm{C}\right)$ & 12.3 & 9.4 & 7.9 & 10.2 & 14.1 \\
\hline Precipitation $(\mathrm{mm})$ & 105 & 0 & 3 & 106 & 20 \\
\hline & Oct/17 & Nov/17 & Dec/17 & Jan/18 & Feb/18 \\
\hline Mean maximum temperature $\left({ }^{\circ} \mathrm{C}\right)$ & 20.1 & 22.2 & 24.9 & 24.1 & 23.8 \\
Mean minimum temperature $\left({ }^{\circ} \mathrm{C}\right)$ & 13.2 & 12.7 & 16.4 & 16.7 & 15.3 \\
\hline Precipitation $(\mathrm{mm})$ & 78 & 65 & 142 & 182 & 58 \\
\hline
\end{tabular}

Legend: Jun/17 = June/2017. Jul/17 = July/2017. Aug/17 = August/2017. Sep/17 = September/2017. Oct/17= October/2017. Nov/17 = November/2017. Dec/2017 = December/2017. Jan/18 = January/2018. Feb/18 = February/2018. Source: INMET (2019).

Among the genotypes studied, cultivars Albion, Jonica, and Pircinque have already been evaluated in the South Plateau of the state of Santa Catarina by FAGHERAZZI (2017) and RICHTER (2018). Selections FRF 57.6, FRF 104.1, FRF LAM 119.1, FRF LAM 269.18, and FRF PA 109.2, in turn, have been evaluated in the same region by ZANIN et al. (2019). Genotypes FRF 57.6 and FRF 104.1 were studied by RICHTER (2018). The remaining genotypes were tested in the South Plateau of the state of Santa Catarina for the first time, in this work.

The experimental design was in randomized blocks, with four replicates and plots of 11 plants. The cultivation system used was in the soil of an open field, using beds of approximately $90 \mathrm{~cm}$ in length and 15 $\mathrm{cm}$ of elevation, prepared using an implement coupled to a tractor. The beds were coated with black polyethylene film. The planting spacing adopted was $30 \mathrm{~cm}$ between rows and plants, in a triangle, with three planting rows per bed.

Soil correction and basic fertilization were done based on the recommendations contained in the Manual of Fertilization and Liming for the States of Rio Grande do Sul and Santa Catarina (CQFS-RS/SC 2004). Cover fertilizations were performed weekly by fertigation, using the following products: monoammonium phosphate (MAP) (387.4 g 1000 plants $\left.^{-1}\right)$; potassium sulfate $\left(\mathrm{K}_{2} \mathrm{SO}_{4}\right)$ (312.5 g 1000

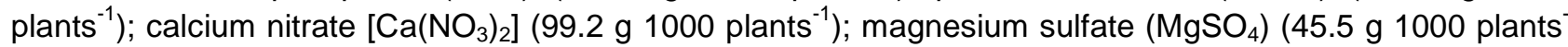
$\left.{ }^{1}\right)$, and a liquid fertilizer containing $51 \%$ phosphorus $\left(73 \mathrm{~mL}^{1000}\right.$ plants $\left.^{-1}\right)$.

Planting was carried out on May $5^{\text {th }}, 2017$, using bare root fresh plants. A drip irrigation system was adopted, with three dripping hoses per bed, provided with drip holes spaced $15 \mathrm{~cm}$ apart. Weed control was done by weeding between the beds and manual scratch in the planting pits. Pest and disease control were performed when necessary using products registered for the crop. Other product used were the acaricide abamectin, insecticide thiametoxan, and fungicides methyl thiophanate (only before the harvest period), fluazinam, iprodione, pyrimethanil, and azoxystrobin + diphenoconazole.

Harvesting was carried out from September $21^{\text {th }}, 2017$ to February $6^{\text {th }}, 2018$. The fruits were picked when presenting at least $80 \%$ of red epidermis. There were a total of 28 harvestings. Intervals between harvesting ranged from three to seven days, according to the availability of ripe fruits. After each harvesting, the fruits were brought to the Food Technology Center (NUTA 2) of the CAV/UDESC, where they were counted and weighed, being discriminated according to the following criteria: A) commercial - fruits with $10 \mathrm{~g}$ or more, without deformities or rotting that depreciate commercial quality; B) small fruits of less than $10 \mathrm{~g}$; C) rotten - fruits containing fungi disease symptoms; D) misshapen - fruits with deformations in the epidermis.

In terms of production, the following variables were obtained at the end of the harvest season: A) total and commercial production ( $\mathrm{g} \mathrm{plant}^{-1}$ ), consisting of the sum of the results of all the harvests, dividing the production in grams by the number of plants present in each plot; $\mathrm{B})$ total estimated yield $\left(\mathrm{t} \mathrm{ha} \mathrm{H}^{-1}\right)$, obtained by multiplying the production per plant by planting density, which was 58,533.64 plants per hectare; C) number of total and commercial fruits per plant (fruits plant ${ }^{-1}$ ); D) average commercial fruit mass $\left(\mathrm{g} \mathrm{fruit}^{-1}\right)$, obtained by dividing the variable commercial production $\left(\mathrm{g} \mathrm{plant}^{-1}\right.$ ) by the variable number of commercial fruits (fruits plant $\left.^{-1}\right)$; E) percentage of commercial, small, rotten, and misshapen fruits (\%), estimated by dividing the fruit production of each category by the total production, and multiplying by 100 . 
The fruits were qualitatively analyzed in the following dates: September $29^{\text {th }}$ and November $10^{\text {th }}, 2017$, and January $10^{\text {th }}, 2018$, corresponding to the beginning, middle, and end of the productive period, respectively. The following evaluations were carried out: A) Color of the epidermis - evaluated using a Konica Minolta ${ }^{\circledR}$ colorimeter. All fruits from each plot were evaluated, consisting of two readings per fruit, one on each side and close to the equatorial diameter, obtaining the variables lightness (L), chroma (c), and hue angle ( ${ }^{\circ}$ hue). B) Pulp firmness - performed using a bench penetrometer, evaluating ten fruits per plot, two readings per fruit, one on each side. The results were expressed in Newtons (N). C) Titratable acidity obtained by titrating a $5 \mathrm{~mL}$ sample of fruit juice from each plot, using $\mathrm{NaOH} 0.1 \mathrm{~N}$ and phenolphthalein as acid-base indicator (IAL 2008). The results were expressed in grams of citric acid per 100 grams of pulp; D) Soluble solids content - analysis performed using a manual refractometer, providing the results in degrees Brix ( ${ }^{\circ}$ Brix). E) Soluble solids/titratable acidity ratio - obtained by the ratio between the soluble solids content values and the titratable acidity of each sample.

The results were submitted to the Shapiro-Wilk normality test and Levènne variance homogeneity, using the R software (R CORE TEAM 2013). When these conditions were met, the data were submitted to analysis of variance and the averages were grouped by the Scott-Knott test at $5 \%$ probability using the Sisvar software (FERREIRA 2011). The statistical model used was as follows: $Y i j=\mu+T i+B j+\varepsilon i j$; in which Yij correspond to the observed value of the dependent variable; $\mu$ is the general average for the variable in question; $\mathrm{Ti}$ is the treatment effect (genotype); Bj correspond to the block effect; and $\varepsilon_{\mathrm{ij}}$ is the residual error.

The data of total and commercial production $\left(\mathrm{g} \mathrm{plant}^{-1}\right)$, total and commercial yield $\left(\mathrm{t}\right.$ ha $\left.{ }^{-1}\right)$, number of

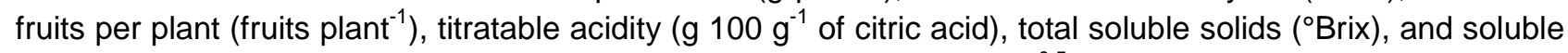
solids/titratable acidity ratio were transformed using the formula $Y=x^{0.5}$. The data on percentage of fruits classified as commercial and small $(\%)$ were transformed by the formula $Y=\operatorname{arc} \sin (x / 100)^{0.5}$, and the percentage of rotten and misshapen fruit (\%) were transformed by the formula $Y=(x+1)^{0.5}$.

\section{RESULTS AND DISCUSSION}

The evaluated cultivars and selections differed for all production variables analyzed. Four groups of averages for total and commercial production per plant, and yield per hectare were formed (Table 2). The Sabrina cultivar showed the best results, differing from all genotypes evaluated. The total and commercial production estimates obtained from the Sabrina cultivar were, respectively, $65.8 \%$ and $77.0 \%$ higher than general averages for these variables. The second group with best results for total production were composed by Pircinque, FRF PA 109.2, FRF PIR 79.6, and Jonica. For commercial production, a second group with the best results was formed by FRF PA 109.2, Pircinque, and FRF PIR 79.6.

RONQUE et al. (2013) state that high yields are important to ensure the economic return necessary to make crops viable, especially in crops typically farmed in small areas, as is the case for strawberries. In many family farms the area planted with strawberries has approximately 0.3 hectare. According to these authors, in a cultivation area of this magnitude, it may be necessary to obtain productions superior to $800 \mathrm{~g}$ per plant to ensure a positive investment balance, due to the oscillations of other factors, such as the cost of seedlings and inputs and, especially, the value of commercialization.

Regarding for the total number of fruits per plant (Table 3), cultivars Sabrina, Pircinque, and Jonica composed the group with the highest averages. The Sabrina cultivar obtained the best result for number of commercial fruits, differing from all other genotypes. This cultivar also showed averages for number of total and commercial fruits per plant, respectively, 38.6\% and $52.8 \%$ higher than the general averages for these variables. Genotypes Pircinque and FRF PA 109.2, in turn, composed a second group of higher averages for number of commercial fruits per plant.

Concerning the average commercial fruit mass, four groups of averages were formed. The group with the best results was composed by the genotypes Sabrina, FRF PA 109.2, and Albion. The average commercial fruit mass obtained by the Sabrina cultivar was $17.1 \%$ higher than the general average for this variable. FAGHERAZZI (2017) also found one of the highest average fruit masses in the cultivar Albion, among 21 genotypes evaluated. 
Table 2. Fruit production in different cultivars and advanced selections of strawberry. Lages, SC, CAV/UDESC, 2018.

\begin{tabular}{|c|c|c|c|c|}
\hline \multirow{2}{*}{ Genotype } & \multicolumn{2}{|c|}{ Production (g plant ${ }^{-1}$ ) } & \multicolumn{2}{|c|}{ Yield $\left(\mathrm{t} \mathrm{ha}^{-1}\right)$} \\
\hline & Total $^{*}$ & Commercial $^{*}$ & Total $^{*}$ & Commercial $^{\star}$ \\
\hline Jonica (SD) & $800.69 \mathrm{~b}$ & $568.94 \mathrm{c}$ & $46.87 \mathrm{~b}$ & $33.30 \mathrm{c}$ \\
\hline Pircinque (SD) & $936.59 \mathrm{~b}$ & $708.31 \mathrm{~b}$ & 54.82 b & $41.46 \mathrm{~b}$ \\
\hline Sabrina (SD) & $1,231.77 \mathrm{a}$ & $1,016.00 \mathrm{a}$ & $72.10 \mathrm{a}$ & $59.47 \mathrm{a}$ \\
\hline FRF LAM 119.1 (SD) & $680.32 \mathrm{c}$ & $511.78 \mathrm{c}$ & $39.82 \mathrm{c}$ & $29.96 \mathrm{c}$ \\
\hline FRF LAM 263.1 (SD) & $683.19 \mathrm{c}$ & $496.58 \mathrm{c}$ & $39.99 \mathrm{c}$ & 29.07 c \\
\hline FRF LAM 269.18 (SD) & $711.60 \mathrm{c}$ & 530.07 c & $41.65 \mathrm{c}$ & $31.03 \mathrm{c}$ \\
\hline FRF PA 109.2 (SD) & $919.98 \mathrm{~b}$ & $761.95 b$ & $53.85 b$ & $44.60 \mathrm{~b}$ \\
\hline FRF PIR 75.8 (SD) & $635.16 \mathrm{c}$ & $552.89 \mathrm{c}$ & $37.18 \mathrm{c}$ & $32.36 \mathrm{c}$ \\
\hline FRF PIR 79.6 (SD) & $840.99 b$ & $665.67 \mathrm{~b}$ & $49.23 \mathrm{~b}$ & $38.96 \mathrm{~b}$ \\
\hline FRF PIR 256.4 (SD) & $555.64 \mathrm{~d}$ & $450.83 d$ & $32.52 \mathrm{~d}$ & $26.39 \mathrm{~d}$ \\
\hline Albion (DN) & $641.11 \mathrm{c}$ & $509.90 \mathrm{c}$ & $37.53 \mathrm{c}$ & $29.85 \mathrm{c}$ \\
\hline Irma (DN) & $542.70 \mathrm{~d}$ & $382.90 \mathrm{~d}$ & $31.77 d$ & $22.41 \mathrm{~d}$ \\
\hline FRF 57.6 (DN) & $759.94 \mathrm{c}$ & $578.55 \mathrm{c}$ & $44.48 \mathrm{c}$ & $33.86 \mathrm{c}$ \\
\hline FRF $104.1(\mathrm{DN})$ & $688.05 \mathrm{c}$ & $488.51 \mathrm{c}$ & $40.27 \mathrm{c}$ & $28.59 \mathrm{c}$ \\
\hline FRF $191.2(\mathrm{DN})$ & $515.18 d$ & $387.64 \mathrm{~d}$ & $30.16 \mathrm{~d}$ & $22.69 \mathrm{~d}$ \\
\hline Mean & 742.86 & 574.03 & 43.48 & 33.60 \\
\hline CV (\%) & 8.30 & 8.75 & 8.30 & 8.75 \\
\hline
\end{tabular}

Means followed by equal letters in the column belong to the same group by the Scott-Knott test $(p \leq 0.05)$.

${ }^{*}$ Data transformed by the formula $Y=x^{0.5}$. Legend: $S D=$ Short Day Genotypes; $D N=$ Day-neutral Genotypes.

Table 3. Number of total and commercial fruits per plant, and average weight of commercial fruits of cultivars and advanced selections of strawberry. Lages, SC, CAV/UDESC, 2018.

\begin{tabular}{lccc}
\hline \multirow{2}{*}{ Genotype } & \multicolumn{2}{c}{ NF (fruits plant ${ }^{-1}$ ) } & \multirow{2}{*}{ AWCF $\left(\right.$ fruit $^{-1}$ ) } \\
\cline { 2 - 3 } Jonica (SD) & Total $^{*}$ & Commercial $^{*}$ & $18.62 \mathrm{~b}$ \\
Pircinque (SD) & $73.87 \mathrm{a}$ & $30.56 \mathrm{c}$ & $17.65 \mathrm{c}$ \\
Sabrina (SD) & $74.24 \mathrm{a}$ & $40.37 \mathrm{~b}$ & $21.10 \mathrm{a}$ \\
FRF LAM 119.1 (SD) & $78.48 \mathrm{a}$ & $48.00 \mathrm{a}$ & $17.18 \mathrm{c}$ \\
FRF LAM 263.1 (SD) & $53.95 \mathrm{~b}$ & $29.75 \mathrm{c}$ & $15.58 \mathrm{~d}$ \\
FRF LAM 269.18 (SD) & $64.81 \mathrm{~b}$ & $31.89 \mathrm{c}$ & $18.68 \mathrm{~b}$ \\
FRF PA 109.2 (SD) & $54.27 \mathrm{~b}$ & $28.34 \mathrm{c}$ & $20.57 \mathrm{a}$ \\
FRF PIR 75.8 (SD) & $59.30 \mathrm{~b}$ & $36.91 \mathrm{~b}$ & $18.17 \mathrm{~b}$ \\
FRF PIR 79.6 (SD) & $42.65 \mathrm{c}$ & $30.58 \mathrm{c}$ & $18.69 \mathrm{~b}$ \\
FRF PIR 256.4 (SD) & $57.21 \mathrm{~b}$ & $33.23 \mathrm{c}$ & $18.93 \mathrm{~b}$ \\
Albion (DN) & $35.24 \mathrm{c}$ & $23.66 \mathrm{~d}$ & $19.67 \mathrm{a}$ \\
Irma (DN) & $38.63 \mathrm{c}$ & $25.91 \mathrm{~d}$ & $15.89 \mathrm{~d}$ \\
FRF 57.6 (DN) & $44.00 \mathrm{c}$ & $24.11 \mathrm{~d}$ & $17.31 \mathrm{c}$ \\
FRF 104.1 (DN) & $64.31 \mathrm{~b}$ & $33.67 \mathrm{c}$ & $15.93 \mathrm{~d}$ \\
FRF 191.2 (DN) & $61.77 \mathrm{~b}$ & $30.49 \mathrm{c}$ & $16.28 \mathrm{~d}$ \\
\hline Mean & $46.78 \mathrm{c}$ & $23.84 \mathrm{~d}$ & 18.02 \\
\hline CV (\%) & 56.63 & 31.42 & 5.89 \\
\hline
\end{tabular}

Means followed by equal letters in the column belong to the same group by the Scott-Knott test $(p \leq 0.05)$.

${ }^{*}$ Data transformed by the formula $Y=x^{0.5}$. Legend: NF $=$ number of fruits per plant; AWCF $=$ average weight of commercial fruits; SD = Short Day Genotypes; DN = Day-neutral Genotypes. 
The number and weight of fruits are the main components of strawberry production (OLIVEIRA \& BONOW 2012). According to SINGH et al. (2018), the number of flowers per plant, length and width of the fruit, and plant vigor also correlate positively with the yield. The same authors found that the yield had the highest genotypic coefficient of variation and genetic advance among many characteristics studied. MISHRA et al. (2015) obtained heritability values in the broad sense of 74.81 and $85.17 \%$ for number of fruits per plant and average fresh weight of fruits, respectively, indicating that these characteristics are strongly influenced by the genotype, and that the correct selection of cultivars is essential to achieve high production parameters.

Regarding fruit production in different categories, there was a significant difference between the cultivars and selections evaluated for the four classification categories (Table 4). Two groups of averages were formed for the fruits classified as commercial. The best group was composed by the genotypes FRF PIR 75.8, FRF PA 109.2, Sabrina, FRF PIR 256.4, Albion, and FRF PIR 79.6. The genotypes that provided a higher number of small fruits, in turn, were FRF 104.1, Írma, FRF LAM 263.1, and Jonica. Higher percentages of misshapen fruits were observed in FRF LAM 269.18, FRF LAM 119.1, Albion, FRF PIR 256.4, and FRF 191.2, and rotten fruits, in FRF PIR 256.4, FRF LAM 119.1, Jonica, and Pircinque.

Table 4. Percentage of total production in different categories for strawberry genotypes. Lages, SC, CAV/UDESC, 2018.

\begin{tabular}{lcccc}
\hline \multirow{2}{*}{ Genotype } & \multicolumn{3}{c}{ Percent of fruits in different categories (\%) } \\
\cline { 2 - 5 } & Commercial $^{*}$ & Small $^{\star}$ & Misshapen $^{\star *}$ & Rotten $^{* *}$ \\
\hline Jonica (SD) & $71.10 \mathrm{~b}$ & $24.45 \mathrm{a}$ & $0.79 \mathrm{~b}$ & $3.67 \mathrm{a}$ \\
Pircinque (SD) & $75.57 \mathrm{~b}$ & $19.03 \mathrm{~b}$ & $1.76 \mathrm{~b}$ & $3.64 \mathrm{a}$ \\
Sabrina (SD) & $82.43 \mathrm{a}$ & $14.88 \mathrm{c}$ & $1.00 \mathrm{~b}$ & $1.69 \mathrm{~b}$ \\
FRF LAM 119.1 (SD) & $75.40 \mathrm{~b}$ & $14.65 \mathrm{c}$ & $4.71 \mathrm{a}$ & $5.24 \mathrm{a}$ \\
FRF LAM 263.1 (SD) & $72.74 \mathrm{~b}$ & $25.53 \mathrm{a}$ & $0.34 \mathrm{~b}$ & $1.39 \mathrm{~b}$ \\
FRF LAM 269.18 (SD) & $74.32 \mathrm{~b}$ & $17.18 \mathrm{c}$ & $6.44 \mathrm{a}$ & $2.07 \mathrm{~b}$ \\
FRF PA 109.2 (SD) & $83.00 \mathrm{a}$ & $12.78 \mathrm{~d}$ & $1.69 \mathrm{~b}$ & $2.54 \mathrm{~b}$ \\
FRF PIR 75.8 (SD) & $86.87 \mathrm{a}$ & $10.20 \mathrm{~d}$ & $0.28 \mathrm{~b}$ & $2.64 \mathrm{~b}$ \\
FRF PIR 79.6 (SD) & $79.60 \mathrm{a}$ & $20.49 \mathrm{c}$ & $2.02 \mathrm{~b}$ & $1.38 \mathrm{~b}$ \\
FRF PIR 256.4 (SD) & $80.87 \mathrm{a}$ & $10.44 \mathrm{~d}$ & $3.03 \mathrm{a}$ & $5.66 \mathrm{a}$ \\
Albion (DN) & $79.75 \mathrm{a} \mathrm{a}^{*}$ & $13.90 \mathrm{c}$ & $3.75 \mathrm{a}$ & $2.59 \mathrm{~b}$ \\
Irma (DN) & $71.04 \mathrm{~b}$ & $25.89 \mathrm{a}$ & $1.66 \mathrm{~b}$ & $1.42 \mathrm{~b}$ \\
FRF 57.6 (DN) & $76.01 \mathrm{~b}$ & $20.25 \mathrm{~b}$ & $1.20 \mathrm{~b}$ & $2.54 \mathrm{~b}$ \\
FRF 104.1 (DN) & $70.61 \mathrm{~b}$ & $26.65 \mathrm{a}$ & $0.90 \mathrm{~b}$ & $1.85 \mathrm{~b}$ \\
FRF 191.2 (DN) & $74.92 \mathrm{~b}$ & $23.63 \mathrm{~b}$ & $2.68 \mathrm{a}$ & $1.92 \mathrm{~b}$ \\
\hline Mean & 76.95 & 18.22 & 2.15 & 2.68 \\
\hline CV (\%) & 4.62 & 10.89 & 28.50 & 25.58 \\
\hline
\end{tabular}

Means followed by equal letters in the column belong to the same group by the Scott-Knott test $(p \leq 0.05)$.

${ }^{*}$ Data transformed by the formula $Y=\arcsin (x / 100)^{0.5}$. ${ }^{* *}$ Data transformed by the formula $Y=(x+1)^{0.5}$.

Legend: SD = Short Day Genotypes; DN = Day-neutral Genotypes.

The percentage of marketable fruits is one of the main production parameters, given that it directly interferes with the economic viability of the investment. The large size and the appropriate external appearance value the fruits in the market and facilitate commercialization, considering that the external aspect is the first factor consumers look to when choosing the product (CARPENEDO et al. 2016). Moreover, it is more advantageous for the farmer to obtain high yields of large fruits than with a high number of small fruits per plant (RICHTER 2018). This is because the exaggerated production of small fruits makes harvesting more expensive and time consuming, and can also increase labor costs, which is an important component in the production cost of the strawberry crop (RONQUE et al. 2013).

The production of misshapen fruits, in turn, may be a consequence of the genetic load since some genotypes are more likely than others to obtain fruits of this type, regardless of the environmental conditions 
(ARIZA et al. 2012). Environmental factors, on the other hand, seem to exert little influence on this parameter since the main environmental cause of this problem is failure in pollination, which for strawberry crops is done mainly by wind and hymenoptera insects (MALAGODI-BRAGA \& KLEINERT 2007). Considering that the experiment was conducted without cover, the wind and insects had free reign throughout the cycle. Regarding fruits with rot, the genotypes with the highest production of fruits in this category are possibly more susceptible to the fungi Botrytis cinerea and Colletotrichum acutatum, important causal agents of fruit rot in strawberry crops (CORDOVA et al. 2017).

There was a difference between the evaluated genotypes for all qualitative variables. The epidermis color was evaluated by considering three variables (Table 5). Cultivars Jonica and Pircinque obtained the highest average of lightness, whereas Albion showed the darkest fruits. Fruits with higher averages for chroma were observed in FRF 57.6, Jonica, Pircinque, FRF PIR 79.6, FRF LAM 119.1, FRF PIR 256.4, FRF PA 109.2, and FRF PIR 75.8. Three groups of averages were formed for hue angle. The group with the highest average was composed by genotypes Jonica, Irma, Pircinque, FRF LAM 119.1, FRF PIR 79.6, FRF PIR 256.4, FRF PA 109.2, and FRF LAM 263.1.

Table 5. Color of the epidermis in fruits of cultivars and advanced selections of strawberry. Lages, SC, CAV/UDESC, 2018.

\begin{tabular}{llll}
\hline \multirow{2}{*}{ Genotype } & \multicolumn{2}{l}{ Epidermis color } & Hue \\
\cline { 2 - 4 } & Lightness & Chroma & $34.98 \mathrm{a}$ \\
Jonica (SD) & $40.25 \mathrm{a}$ & $48.69 \mathrm{a}$ & $34.11 \mathrm{a}$ \\
Pircinque (SD) & $39.55 \mathrm{a}$ & $48.13 \mathrm{a}$ & $29.93 \mathrm{c}$ \\
Sabrina (SD) & $35.60 \mathrm{c}$ & $44.81 \mathrm{~b}$ & $33.82 \mathrm{a}$ \\
FRF LAM 119.1 (SD) & $37.93 \mathrm{~b}$ & $47.18 \mathrm{a}$ & $32.16 \mathrm{a}$ \\
FRF LAM 263.1 (SD) & $34.55 \mathrm{c}$ & $44.17 \mathrm{~b}$ & $29.40 \mathrm{c}$ \\
FRF LAM 269.18 (SD) & $34.26 \mathrm{c}$ & $43.89 \mathrm{~b}$ & $33.01 \mathrm{a}$ \\
FRF PA 109.2 (SD) & $37.15 \mathrm{~b}$ & $46.91 \mathrm{a}$ & $29.83 \mathrm{c}$ \\
FRF PIR 75.8 (SD) & $36.49 \mathrm{~b}$ & $46.54 \mathrm{a}$ & $33.70 \mathrm{a}$ \\
FRF PIR 79.6 (SD) & $37.28 \mathrm{~b}$ & $47.43 \mathrm{a}$ & $33.09 \mathrm{a}$ \\
FRF PIR 256.4 (SD) & $36.30 \mathrm{~b}$ & $47.03 \mathrm{a}$ & $28.16 \mathrm{c}$ \\
Albion (DN) & $31.68 \mathrm{~d}^{\star}$ & $42.00 \mathrm{~b}$ & $34.33 \mathrm{a}$ \\
Irma (DN) & $37.86 \mathrm{~b}$ & $45.56 \mathrm{~b}$ & $31.68 \mathrm{~b}$ \\
FRF 57.6 (DN) & $38.34 \mathrm{~b}$ & $48.72 \mathrm{a}$ & $31.60 \mathrm{~b}$ \\
FRF 104.1 (DN) & $35.59 \mathrm{c}$ & $45.80 \mathrm{~b}$ & $30.42 \mathrm{c}$ \\
FRF 191.2 (DN) & $34.21 \mathrm{~b}$ & $44.43 \mathrm{~b}$ & 32.01 \\
\hline Mean & 36.47 & 46.09 & 4.09 \\
\hline CV (\%) & 3.82 & 4.05 & $(p 50.05)$.
\end{tabular}

*Means followed by equal letters in the column belong to the same group by the Scott-Knott test ( $p \leq 0.05)$.

Legend: SD = Short Day Genotypes; DN = Day-neutral Genotypes.

The cultivars with fruits of lighter epidermis, that is, higher average values for the $L$ index, also had a more lively or saturated coloration (higher chroma) and a tonality closer to light red or orange (higher hue angle). This fact was well observable in the Pircinque and Jonica cultivars, which are Italian cultivars characterized by epidermis with a very uniform red-orange coloration. On the other hand, the Albion cultivar presented fruits with darker epidermis and lower values of hue angle, typical of shades closer to dark red.

Fruits with more intense red and bright red color are preferred for in natura consumption (CARPENEDO et al. 2016). According to the same authors, the external coloration of the epidermis is one of the first factors that consumers consider when deciding on a purchase. According to NUNES (2015), fruits with better color are better accepted and present higher content of vitamin C.

The red coloration of the strawberry fruits is due to the presence of pigments belonging to the anthocyanins group. Among the main anthocyanins present in strawberries, pelargonidine 3-glucoside stands out, followed by cyanidin 3-glucoside. COCCO (2014) states that higher concentrations of 
pelargonidin 3-glucosre responsible for the coloration of the dark red epidermis. According to the author, anthocyanins are among the main functional compounds with antioxidant power in strawberries. The effect of genotypes is greater than the environmental effect on the content of these compounds.

Three groups of averages were formed for pulp firmness (Table 6). Most of the evaluated genotypes were arranged in the group with the highest averages. In this sense, the highest average was observed in selection FRF PIR 75.8, which did not differ from other nine genotypes. This selection obtained a result $10.6 \%$ higher than the general average. The group with the lowest scores, in turn, was formed by FRF LAM 119.1 and Albion.

Table 6. Main characteristics of fruit quality in strawberry cultivars and selections. Lages, SC, CAV/UDESC, 2018.

\begin{tabular}{lcccc}
\hline Genotype & PF $(\mathrm{N})$ & $\begin{array}{c}\text { TA }\left(\mathrm{g} 100 \mathrm{~g}^{-1} \text { of }\right. \\
\text { citric acid })^{*}\end{array}$ & ${\text { SST }\left({ }^{\circ} \text { Brix }\right)^{*}}^{*}$ & RT (SS/AT $)^{*}$ \\
\hline Jonica (SD) & $5.22 \mathrm{a}$ & $0.60 \mathrm{~b}$ & $8.58 \mathrm{a}$ & $14.47 \mathrm{c}$ \\
Pircinque (SD) & $5.26 \mathrm{a}$ & $0.56 \mathrm{c}$ & $8.94 \mathrm{a}$ & $15.92 \mathrm{~b}$ \\
Sabrina (SD) & $5.30 \mathrm{a}$ & $0.61 \mathrm{~b}$ & $7.88 \mathrm{~b}$ & $12.89 \mathrm{c}$ \\
FRF LAM 119.1 (SD) & $4.44 \mathrm{c}$ & $0.55 \mathrm{c}$ & $8.43 \mathrm{a}$ & $15.40 \mathrm{~b}$ \\
FRF LAM 263.1 (SD) & $4.91 \mathrm{~b}$ & $0.60 \mathrm{~b}$ & $7.14 \mathrm{~b}$ & $11.99 \mathrm{c}$ \\
FRF LAM 269.18 (SD) & $5.27 \mathrm{a}$ & $0.68 \mathrm{a}$ & $8.22 \mathrm{~b}$ & $12.17 \mathrm{c}$ \\
FRF PA 109.2 (SD) & $5.35 \mathrm{a}$ & $0.54 \mathrm{c}$ & $7.58 \mathrm{~b}$ & $14.12 \mathrm{c}$ \\
FRF PIR 75.8 (SD) & $5.56 \mathrm{a}$ & $0.64 \mathrm{a}$ & $8.00 \mathrm{~b}$ & $12.47 \mathrm{c}$ \\
FRF PIR 79.6 (SD) & $5.39 \mathrm{a}$ & $0.66 \mathrm{a}$ & $8.93 \mathrm{a}$ & $13.59 \mathrm{c}$ \\
FRF PIR 256.4 (SD) & $4.79 \mathrm{~b}$ & $0.47 \mathrm{~d}$ & $9.26 \mathrm{a}$ & $20.87 \mathrm{a}$ \\
Albion (DN) & $4.49 \mathrm{c}$ & $0.68 \mathrm{a}$ & $8.46 \mathrm{a}$ & $12.49 \mathrm{c}$ \\
Irma (DN) & $4.81 \mathrm{~b}$ & $0.66 \mathrm{a}$ & $7.84 \mathrm{~b}$ & $11.96 \mathrm{c}$ \\
FRF 57.6 (DN) & $5.21 \mathrm{a}$ & $0.50 \mathrm{~d}$ & $7.98 \mathrm{~b}$ & $15.87 \mathrm{~b}$ \\
FRF 104.1 (DN) & $5.02 \mathrm{a}$ & $0.49 \mathrm{~d}$ & $8.67 \mathrm{a}$ & $17.79 \mathrm{~b}$ \\
FRF 191.2 (DN) & $5.22 \mathrm{a}$ & $0.59 \mathrm{~b}$ & $7.79 \mathrm{~b}$ & $13.21 \mathrm{c}$ \\
\hline Mean & 5.08 & 0.59 & 8.24 & 14.35 \\
\hline CV (\%) & 5.23 & 7.56 & 9.17 & 5.69 \\
\hline
\end{tabular}

Means followed by equal letters in the column belong to the same group by the Scott-Knott test $(p \leq 0.05) .{ }^{*}$ Data transformed by the formula $Y=x^{0.5}$. Legend: $P F=$ pulp firmness; $T A=$ titratable acidity; $S S T=$ soluble solids content; $\mathrm{RT}=$ soluble solids / titratable acidity ratio; $\mathrm{SD}=$ Short Day Genotypes; $\mathrm{DN}=$ Day-neutral Genotypes.

For titratable acidity, four groups of averages were formed. The group with higher averages was composed by the genotypes Albion, FRF LAM 269.18, Irma, FRF PIR 79.6, and FRF PIR 75.8. The group with the lowest results was formed by FRF PIR 256.4, FRF 104.1, and FRF 57.6. There was a difference of $44.7 \%$ between the lowest average, verified in the selection FRF PIR 256.4 ( $0.47 \mathrm{~g} 100 \mathrm{~g}^{-1}$ of citric acid) and

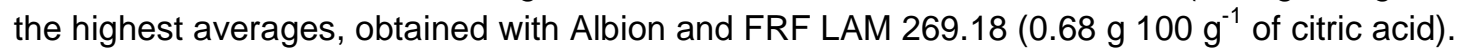

The content of soluble solids formed two groups of averages. Genotypes FRF PIR 256.4, Pircinque, FRF PIR 79.6, FRF 104.1, Jonica, Albion, and FRF LAM 119.1 composed the groups with the best results. Selection FRF PIR 256.4 presented soluble solid content $12.4 \%$ higher than the general average. The same genotype obtained the highest average for the soluble solids/titratable acidity ratio, with a result $45.4 \%$ higher than the general average, and differed from all other treatments. The second group with the best results for soluble solids/titratable acidity ratio was composed by FRF 104.1, Pircinque, FRF 57.6, and FRF LAM 119.1.

The high soluble solids/titratable acidity ratio in the Pircinque cultivar has already been reported by FAGHERAZZI (2017). Regarding selections FRF 57.6, FRF 104.1, FRF LAM 119.1, and FRF PIR 256.4, even if not registered as new cultivars, they can be used in new hybridizations aiming at incrementing fruit quality.

The firmness of pulp is one of the most important characteristics and is among the most sought after in the genetic improvement of strawberry. Firm fruits are more resistant to damages during transport and have 
longer post-harvest durability and resistance to rot (OLIVEIRA \& BONOW 2012). The possibility of storing the product for an extended time and marketing to more distant locations is a great advantage for producers, especially in the case of highly perishable fruits such as strawberries and other small fruits (BRACKMANN et al. 2011).

Additionally, all the most productive genotypes studied in this paper - Sabrina, FRF PA 109.2, Pircinque, and FRF PIR 79.6 - were allocated in the group with the highest averages of pulp firmness. This result suggests that it is possible to select cultivars that are both productive and bear firm fruits.

The acidity of the strawberry pulp is conditioned by the presence of several organic acids, among which are the citric and ascorbic acids (HANCOCK et al. 2008). The organic acids are degraded during the ripening process, reducing their content concomitantly with the increase in the concentration of soluble sugars (MATARAZZO et al. 2013). For in natura consumption, the acidity of the pulp cannot be very high since it can compromise consumer acceptance of the fruits (RESENDE et al. 2008).

The content of soluble solids, on the other hand, is conditioned by the presence of several polysaccharides, among which are glucose, fructose and sucrose (HANCOCK et al. 2008). The concentration of these compounds in fruits increases during the preharvest maturation process, when the reserve starch is converted into simpler, water-soluble carbohydrates (MATARAZZO et al. 2013). Since the strawberry is a non-climacteric fruit, the values of total acidity, soluble solids content, and soluble solids/titratable acidity ratio fluctuate slightly during the storage period (ANDRADE JÚNIOR et al. 2016).

The soluble solids/titratable acidity ratio, in turn, is one of the most important qualitative variables. In a commercial cultivar, it is imperative that there is an adequate balance between acidity and soluble solids content (CARPENEDO et al. 2016). RESENDE et al. (2008) reported that strawberries with higher soluble solids/titratable acidity ratio are the most accepted for in natura consumption. Strawberry cultivars must present the following parameters for fresh fruit commercialization: at least $7.0^{\circ}$ Brix for soluble solids content;

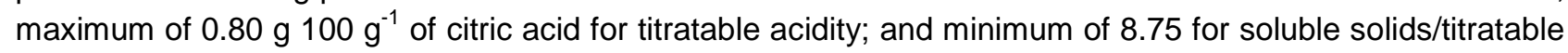
acidity ratio (KADER 2002, cited by SOUZA et al. 2017). Following these concepts, all genotypes evaluated in this paper can be considered adequate for in natura commercialization.

\section{CONCLUSION}

The cultivar Sabrina had the highest yield among genotypes evaluated, followed by FRF PA 109.2, Pircinque and FRF PIR 79.6. In turn, Sabrina, FRF PA 109.2 and Albion had the largest fruits.

The selections FRF PIR 256.4, FRF 104.1, FRF 57.6 and FRF LAM 119.1, and the cultivar Pircinque present good fruit quality, expressed by high values for soluble solids / titratable acidity ratio.

In the conditions in which the study was carried out, the genotypes Sabrina, Pircinque and PA 109.2 presented promising agronomic characteristics for commercial scale cultivation.

\section{ACKNOWLEDGEMENTS}

The first author thank to the Coordenação de Aperfeiçoamento de Pessoal de Nível Superior (CAPES) for the award of the scholarship.

\section{REFERENCES}

ANDRADE JÚNIOR VC et al. 2016. Conservação pós-colheita de frutos de morangueiro em diferentes condições de armazenamento. Horticultura Brasileira 34: 405-411.

ANTUNES LEC \& PERES NA. 2013. Strawberry Production in Brazil and South America. International Journal of Fruit Science 13: 156-161.

ARIZA MT et al. 2012. Incidence of misshapen fruits in strawberry plants grown under tunnels is affected by cultivar, planting date, pollination, and low temperatures. HortScience 47: 1569-1573.

BRACKMANN A et al. 2011. Avaliação de genótipos de morangueiro quanto à qualidade e potencial de armazenamento.

Revista Ceres 58: 542-547.

CARPENEDO $S$ et al. 2016. Caracterização sensorial de morangos cultivados na região de Pelotas. Horticultura Brasileira 34: 565-570.

COCCO C. 2014. Produção e qualidade de mudas e frutas de morangueiro no Brasil e na Itália. Tese (Doutorado em Agronomia). Pelotas: UFPEL. 124p.

CORDOVA LG et al. 2017. Meta-Analysis of a Web-Based Disease Forecast System for Control of Anthracnose and Botrytis Fruit Rots of Strawberry in Southeastern United States. Plant Disease 101: 1910-1917. 
COSTA AF et al. 2016. Biplot analysis of strawberry genotypes recommended for the State of Espírito Santo. Genetics and Molecular Research 15: 1-9.

CQFS-RS/SC. 2004. Manual de adubação e calagem para os estados do Rio Grande do Sul e Santa Catarina. 10.ed. Porto Alegre: Comissão de Química e Fertilidade do Solo. 404p.

FAGHERAZZI AF. 2017. Adaptabilidade de novas cultivares e seleções de morangueiro para o Planalto Sul Catarinense. Tese (Doutorado em Produção Vegetal). Lages: UDESC. 144p.

FAGHERAZZI AF. 2013. Avaliação de cultivares de morangueiro no Planalto Sul Catarinense. Dissertação (Mestrado em Produção Vegetal). Lages: UDESC. 107p.

FAGHERAZZI AF et al. 2017(a). Strawberry production progress in Brazil. Acta Horticulturae 1156: 937-940.

FAGHERAZZI AF et al. 2017(b). New strawberry cultivars and breeding acitivities in Brazil. Acta Horticulturae 1156: 167170.

FAO. 2019. Food and Agriculture Organization of the United Nations. Crops. Available in: http://www.fao.org/faostat/en/\#data/QC/visualize. Accessed in: 17 apr. 2019.

FERREIRA DF. 2011. Sisvar: a computer statistical analysis system. Ciência e Agrotecnologia 35: 1039-1042.

HANCOCK JF et al. 2008. Strawberries. In: HANCOCK JF. (Ed.). Temperate Fruit Crop Breeding. Dordrecht: Springer. p.393-437.

HONJO M et al. 2016. Simple sequence repeat markers linked to the everbearing flowering gene in long-day and dayneutral cultivars of the octoploid cultivated strawberry Fragaria $\times$ ananassa. Euphytica 209: 291-303.

IAL. 2008. Instituto Adolfo Lutz. Métodos físico-químicos para análise de alimentos. 4.ed. São Paulo: IAL. 1020p.

INMET. 2019. Instituto Nacional de Meteorologia. Estações Automáticas - Gráficos. Available in: http://www.inmet.gov.br/portal/index.php?r=home/page\&page=rede_estacoes_auto_graf. Accessed in: 24 jun. 2019.

KADER AA. 2002. Standardization and Inspection of Fresh Fruits and Vegetables. In: KADER AA. (Ed.). Postharvest Technology of Horticultural Crops. 3.ed. Oakland: University of California. p.287-300.

MALAGODI-BRAGA KS \& KLEINERT AMP. 2007. Como o comportamento das abelhas na flor do morangueiro (Fragaria ananassa Duchesne) influencia a formação dos frutos? Bioscience Journal 23: 76-81.

MATARAZZO PHM et al. 2013. Desenvolvimento dos frutos de lulo (Solanum quitoense Lam.) em Viçosa-MG. Revista Brasileira de Fruticultura 35: 131-142.

MISHRA PK et al. 2015. Genetic variability, heritability, and genetic advance in strawberry (Fragaria $\times$ ananassa Duch.). Turkish Journal of Agriculture and Forestry 39: 451-458.

NUNES MCN. 2015. Correlations between subjective quality and physicochemical attributes of fresh fruits and vegetables. Postharvest Biology and Technology 107: 43-54.

OLIVEIRA ABC \& BONOW S. 2012. Novos desafios para o melhoramento genético da cultura do morangueiro no Brasil. Informe Agropecuário 33: 21-26.

PÁDUA JG et al. 2015. Comportamento de cultivares de morangueiro em Maria da Fé e Inconfidentes, sul de Minas Gerais. Revista Agrogeoambiental 7: 69-79.

R CORE TEAM. 2013. R: A language and environment for statistical computing. Vienna: R Foundation for Statistical Computing. Available in: https://www.r-project.org/. Accessed in: 28 nov. 2018.

RESENDE JTV et al. 2008. Sensory analysis and chemical characterization of strawberry fruits. Horticultura Brasileira 26: 371-374.

RICHTER AF. 2018. Produção e qualidade de genótipos de morangueiro em diferentes sistemas de cultivo. Dissertação (Mestrado em Produção Vegetal). Lages: UDESC. 105p.

RONQUE ERV et al. 2013. Viabilidade da cultura do morangueiro no Paraná-BR. Revista Brasileira de Fruticultura 35 : 1032-1041.

SINGH G et al. 2018. Genetic variability and association analysis in strawberry (Fragaria x ananassa Duch). Electronic Journal of Plant Breeding 9: 169-182.

SOUZA DC et al. 2017. Propriedades físico-químicas em frutos de híbridos experimentais de morangueiro. Agrotrópica 29: 85-96.

ZANIN DS et al. 2019. Agronomic performance of cultivars and advanced selections of strawberry in the South Plateau of Santa Catarina State. Revista Ceres 66: 159-167. 